\title{
Instinctually Mental
}

\author{
Karabo Motswagae* \\ Rio Invetec, Gaborone, Botswana \\ Submission: April 04, 2018; Published: April 25, 2018 \\ *Corresponding author: Motswagae K, Executive Assistant to Chief Executive Officer at Rio Invetec, Botswana, Tel: +27718010839 , \\ E-mail: karabomotswagae@outlook.com
}

Abstract

In abstract of all written, may God bless every soul with this writing instinctually mental.

Keywords: Instinctually; Mental; God; Bless; Souls

\section{Introduction}

A black particle realized as heat transgressed to one thought of New World Order in becoming of the future now known as Science. One boy realized instinctual to take over every monarch realized in the church of the kingdom. Argued God till no one could tell any different in the spirit realized in his soul. Argued art till no man could speak if abstract in his writing. Argued spirit till no mind could realize soulful of the boy's connections in understanding of the message in transcript mentally in control of the thought. He argued but one conscious realized for so long no forefather could begin to beg the thought of constitution. Now begonia to think intellectually of the political arguments to come in debate of his new discovery. What does this boy argue? Instinctual of mentality so realized it controls you. At what writing may a writer write this way?

Only one of a writer with the power to. Not physically but mentally at the conscious of a thought. I hold your argument! Now written, the boy describes himself as instinctual mental because no fathom has imagined this thought in the conscious mind. Now thought of as something belonging, the boys asks for donation. Due to unprivileged background, it remains only hope. As for the boy, his writing will always be the best known to man of the historical thought in memory past of all knowledge realized with understanding to mentality. All description passed with message to encryption. All explanation thought in visual. All judgement analysed in photographic intelligence. The boy asks for charity to his cause as his argument is too conditional to his environment. Be it his surroundings, be it his climate of locality, and be it his temperature of local reference. All that is asked remains cause to effect of effort engraved into the soul of his instinctual argument. All controlled shall conform. All who wrote shall be borne. All who spoke may be wished. All who devote will be praised upon mentality of God prayer to the worthless pheasant known to think of speech in recognition to the voice, however, to the thought. Realm of praise. Given to thee in name. Upon he who gave. Unto him who slaved.

\section{Body}

Preposition to objective sentiment proposed of wording too strong to note. An opaque question to beg in plain sight, what motivation do you have to override me? I only speak of translucent journeys with transparent quests... Subjective to the monarch, the little boy rode with dire men in hunger of survival. Obedient to the throne, he returned with nothing but asked for. Prayer to the God he whom saved by his conscious effort will always be realized. An instinctual argument no one can debate. However, still questioned of the thought, why has this become overwhelming? Well was this not what you asked in wish of praise to the pope genie queen. Instinctually is opportunity to the kingdom not realized mentality but thought provoking in conscious. Not thought in soul but heard in spirit. Never questioned in doubt, but fathomed in trouble. What will he do? Is that not instinctually praised? May prayer be to those who realize instinctual? As power will be upon your hands to integrate to a deep mentality of conscious. Survival of the fittest state of mind. Life of the strongest awareness of heart. Spirit of the uttermost humble merciful soul. May God bless you with your argument? May he portray you in your image? May his wish grace you with your thought of adrenalin as you thought control was out of your reach, but within fine hindsight of your metempsychosis? God becoming your argument now controls you till you may move on with your normal self, realized as instinct.

\section{Results}

In god may the kingdom write be of his wish forever -Karabo Motswagae. 
- Quality Editorial service

- Swift Peer Review

- Reprints availability

- E-prints Service

- Manuscript Podcast for convenient understanding

- Global attainment for your research

- Manuscript accessibility in different formats

( Pdf, E-pub, Full Text, Audio)

- Unceasing customer service

Track the below URL for one-step submission https://juniperpublishers.com/online-submission.php 